\title{
The Human Mammary Gland as a Target for Isoflavones: How Does the Relation Vary in Individuals with Different Ethnicity?
}

Author

Affiliation

\author{
Gertraud Maskarinec
}

University of Hawaii Cancer Center, Honolulu, HI, USA

\author{
Key words \\ - soy isoflavones \\ - breast tissue \\ - cancer \\ - ethnicity \\ - estrogens \\ - biomarkers
}

received July 3,2012

revised Sept. 24, 2012

accepted October 20, 2012

Bibliography

DOI http://dx.doi.org/

$10.1055 / \mathrm{s}-0032-1327953$

Published online November 23 , 2012

Planta Med 2013; 79: 554-561

(c) Georg Thieme Verlag KG

Stuttgart · New York .

ISSN 0032-0943

\section{Correspondence}

Gertraud Maskarinec, MD, PhD

University of Hawaii Cancer

Center

1236 Lauhala Street

Honolulu, HI 96813

USA

Phone: +18085863078

Fax: +18085862982

gertraud@cc.hawaii.edu

\section{Abstract \\ $\nabla$}

Based on observational studies, it appears that soy food consumption provides protection against breast cancer primarily in Asian but not in Western populations. Given the problems in examining the effects of isoflavones directly in the human mammary gland, this review describes epidemiologic studies that investigated the association with biomarkers reflecting hormonal activity of isoflavones, in particular sex steroid levels, mammographic densities, nipple aspirate fluid, and tissue specimens from biopsies or surgeries. Three possible mechanisms that may be responsible for ethnic-specific health effects from these compounds are discussed: genetic variation in metabolic enzymes, timing of exposure, and intestinal metabolism by microbiota. Only a limited number of comparative studies and even fewer nutritional interventions have examined effects and addressed differences in biomarkers between Asian and Western populations. Investigations that looked at estrogens and mammographic den-

\section{Introduction}

$\checkmark$

Soy foods have been part of traditional Asian diets for many centuries but were introduced in Western countries only a few decades ago [1]. Migrants from Asia maintained their dietary habits to a certain degree when they moved to Western countries, but they also adopted local foods [2]. Research into the protective effects of soy foods was inspired by the low incidence of breast cancer among Asian women - respective 2008 rates of $76,42.7$, and 21.6 per 100000 women in the US, Japan, and China were reported [3] - and by Japanese migrant studies showing an increase in breast cancer risk over 2-3 generations [4]. Due to the estrogen-like structure of isoflavones found in soy beans and the known role of estro- sities as endpoints observed some associations in Asian women that were not seen in Caucasians. On the other hand, the low rate of nipple aspirate fluid production and a lack of breast tissue studies make it impossible to evaluate effects of isoflavones on these biomarkers in Asian women. Based on the current evidence, it appears likely that the timing of exposure is the most important determinant of beneficial health effects from soy foods. This may be the result of gut microbiota, which colonize the intestine during childhood and facilitates the hydrolysis of glycosides and the formation of equol from dadzein, a pathway that may result in beneficial health effects. The current evidence is insufficient to answer the question whether women of diverse ethnic groups experience distinct effects from soy isoflavones in breast tissue, but as knowledge about the role of early life nutrition and the development of gut microbiota increases, the potential for diverse metabolic pathways of isoflavones in individuals with different ethnic backgrounds and dietary exposures may be clarified.

gens in breast carcinogenesis [5], most soy research has focused on the hormonal activity of these compounds despite the many other hypothesized biologic mechanisms of action that may contribute to chemoprevention and possibly cancer therapy [6-9].

As demonstrated in several meta-analyses [1014], support for a breast cancer protective effect of soy is much stronger among women of Asian, primarily Japanese and Chinese, ancestry than for Western populations. The respective risk estimates in two meta-analyses were 0.71 (95\% CI: $0.60-0.85$ ) and 0.76 (95\% CI: 0.65-0.86) for Asian populations, while no association was seen in Western women $[13,14]$. This discrepancy could be due to the low soy intake in Western women and the fact that Asians typically eat whole soy 
foods, whereas soy products in Western countries tend to be highly processed or consumed as single soy components [15]. A recent case-control analysis nested within the Multiethnic Cohort in Hawaii and Los Angeles found similar results in an examination of urinary isoflavone excretion as a biomarker of soy intake among 251 cases and 462 controls [16]. The risk associated with breast cancer was 0.69 (95\% CI: 0.51-0.92) among Japanese Americans and 0.98 (95\% CI: 0.61-1.55) among Caucasians [16]. Thus, it appears that not all populations derive the same benefit from exposure to isoflavones and possibly other components of soy foods. Instead, there is reason to believe that these bioactive compounds exert differential actions across individuals depending on their ancestry.

In order to understand the role of soy isoflavones in breast cancer etiology, investigations to explore the action on breast tissue have been conducted in experimental settings. They have shown the ability of isoflavones to bind competitively to estrogen receptors (ER) $\alpha$ and $\beta$, but other biologic actions of mechanisms have also been described $[8,9]$. The binding to ERs may result in stimulation or reduction of estrogenic activity depending on the hormonal milieu [17-19]. Given the challenge of examining breast tissue from healthy women, a variety of markers suspected to be associated with breast cancer have been analyzed as surrogate endpoints.

This review will focus on epidemiologic studies that investigated the association between soy foods and biomarkers reflecting the effects of isoflavones in the breast, in particular hormone levels, mammographic densities, nipple aspirate fluid (NAF), and tissue specimens from biopsies or surgeries. The question to be addressed is whether populations with different ethnicity deal with these plant-based compounds in ways that lead to variations in function and disparate health effects. Three possible underlying mechanisms that may be responsible for ethnic differences will be discussed: genetic variation in metabolic enzymes, timing of exposure, and intestinal metabolism by microbiota.

\section{Soy Isoflavones and Biomarkers for Breast Cancer}

$\nabla$

\section{Sex steroid hormones}

Studies of circulating estrogens and androgens [20] and urinary estrogen metabolites [21-23] have been conducted to elucidate the effect of soy isoflavones on hormonal metabolism. In a single arm intervention, a reduction in luteal phase estradiol $\left(E_{2}\right)$ was observed only among Asian (-17.4\%) but not among non-Asian $(-1.2 \%)$ participants [24]. In a trial with soy milk among Japanese women [25], estrone $\left(E_{1}\right)$ and $E_{2}$ decreased in the intervention group. However, a recent cross-sectional study among more than 400 Japanese women reported no association between soy intake and various sex steroids [26]. Also, a meta-analysis of 47 randomized or carefully controlled intervention studies found no effect of soy or isoflavones on circulating $\mathrm{E}_{1}$ or $\mathrm{E}_{2}$ levels in pre- or postmenopausal women [20]. Although 4 studies examined estrogens in Asian women, their findings were not analyzed separately. Of these, two studies from Japan and one from Taiwan detected nonsignificant decreases in serum estrogen levels $[25,27$, 28 ], while another Japanese investigation reported no effect on $E_{2}$ [29].

As to urinary estrogen metabolite patterns, a cross-sectional study among 430 Asian American women found no association of soy intake with 15 estrogen metabolites assessed by liquid chromatography mass spectrometry (LCMS) but detected a high- er 2/16 $\alpha$-hydroxy $(\mathrm{OH}) \mathrm{E}_{1}$ ratio, a possible marker for lower breast cancer risk, among women with high soy intake [30]. Interventions among premenopausal women reported discrepant findings. An investigation with a soy beverage [31] and with an isoflavone supplement [32] detected no change in urinary estrogen metabolites and the $2 / 16 \alpha-\mathrm{OH}$ ratio. The small number of Asian Americans (11 out 34) was not analyzed separately. A gas chromatography mass spectrometry (GCMS)-based crossover trial in 12 women consuming 10,65 , and $129 \mathrm{mg}$ of isoflavones from soy protein powder for 3 months each described significantly lower $16 \alpha-\mathrm{OHE}_{1}, 4-\mathrm{OHE}_{1}$, and $4-\mathrm{OHE}_{2}$ and a higher $2 /$ $16 \alpha-\mathrm{OHE}_{1}$ ratio after supplement intake [33]. In a similar investigation with 8 women, soy milk with a high isoflavone content (113-202 mg/day) was associated with a higher urinary excretion of $2-\mathrm{OHE}_{1}$ and a higher $2 / 16 \alpha-\mathrm{OHE}_{1}$ ratio [22]. An analysis in Hawaii using GCSM also reported a higher $2 / 16 \alpha-\mathrm{OHE}_{1}$ ratio at the end of the high-soy diet ( $p=0.05)$, but the individual metabolites did not differ significantly by dietary assignment [23]. An interaction term between soy diet and ethnicity was not significant indicating that the $27 \%$ of women of Asian ancestry did not differ from the rest of the study participants. In trials among postmenopausal women, a decrease in the ratio of genotoxic to total estrogens [21] and a higher urinary $2 / 16 \alpha-\mathrm{OHE}_{1}$ ratio [34] were observed, while no change was seen in other interventions [35]. None of the studies included Asian women.

\section{Mammographic density}

Mammographic density refers to the appearance of the human breast in radiologic images and is one of the strongest predictors of breast cancer risk [36]. Women with more than $50 \%$ breast density experience a 4 - to 6 -fold higher risk of breast cancer than those with less than $10 \%$ density [36]. Since women of Asian ancestry tend to have higher mammographic densities than Caucasians due to the small size of their breasts [37], appropriate adjustments are necessary. Two cross-sectional investigations, one in Hawaii [38] and two reports from the same study among Chinese women in Singapore using different measures of mammographic density $[39,40]$ suggest slightly lower breast densities among women of Asian descent with regular soy intake, but two larger studies with Japanese and Chinese women did not report any conclusive evidence $[41,42]$. With great consistency, the randomized trials conducted so far indicate that soy or isoflavones do not modify mammographic densities among adult pre- and postmenopausal Caucasian women $[43,44]$. A meta-analysis of 8 randomized trials suggested no overall effect in all women combined with a mean difference of less than $1 \%$ [44]. So far, no intervention studies with breast density as an outcome were performed among Asian women only and stratification of the Hawaii studies did not suggest any ethnic differences $[45,46]$. The relatively short duration, the small sample sizes, and the age of the study participants are limitations that may have been responsible for a lack of an effect on breast density in the trials presented here as opposed to the weak associations observed in cross-sectional studies [38-40].

\section{Nipple aspirate fluid (NAF)}

Little research on the presence and the effect of isoflavonoids directly in the breast has been undertaken, but the presence of isoflavonoids in breast milk with concentrations of 5-110 nmol/L has been documented [47]. In non-lactating women, nipple aspiration is a noninvasive method to obtain breast fluid and epithelial cells using a device similar to a manual breast pump [48]. Giv- 
Table 1 Nutritional trials exploring the effect of isoflavones/phytoestrogens on nipple aspirate fluid (NAF).

\begin{tabular}{|c|c|c|c|c|}
\hline $\begin{array}{l}\text { Author } \\
\text { Year }\end{array}$ & $\mathbf{N}$ & Intervention & NAF outcomes & Other outcomes \\
\hline $\begin{array}{l}\text { Petrakis et } \\
\text { al. } 1996 \\
\text { [53] }\end{array}$ & $\begin{array}{l}14 \text { pre } \\
10 \text { post }\end{array}$ & $\begin{array}{l}\text { Soy protein } \\
\text { supplement }\end{array}$ & $\begin{array}{l}\text { Premenopausal } \\
\text { Volume: increase; } \mathrm{p}=0.001 \\
\text { GCDFP-15: increase; } \mathrm{p}=0.04 \\
\text { Postmenopausal } \\
\text { Volume: } \text { no significant change } \\
\text { GCDFP-15: } \text { no significant change } \\
\text { Hyperplastic cells: before } 1 / 24 \text {-after } 7 / 24 ; p=0.02\end{array}$ & $\begin{array}{l}\text { Plasma E2: no change } \\
\text { Plasma progesterone: no change } \\
\text { Plasma SHBG: no change } \\
\text { Plasma prolactin: no change }\end{array}$ \\
\hline $\begin{array}{l}\text { Ruhlen et al. } \\
2007 \text { [58] }\end{array}$ & 61 & $\begin{array}{l}\text { Black cohosh } \\
\text { extract }\end{array}$ & $\begin{array}{l}\text { NAF pS2: } \\
\text { Baseline } 3.57 \pm 1.91 \\
\text { } 12 \text { weeks } 1.60 \pm 0.68 \\
\text { N } 24 \text { weeks } 1.01 \pm 0.31 \text {; ns = nonsignificant decrease } \\
\text { NAF cytology: no change }\end{array}$ & $\begin{array}{l}\text { Serum } E_{2}: \text { nonsignificant decrease } \\
\text { Serum LH: no change } \\
\text { Serum FSH: no change } \\
\text { Serum pS2: nonsignificant decrease } \\
\text { Menopausal symptoms: significant decrease }\end{array}$ \\
\hline $\begin{array}{l}\text { Maskarinec } \\
\text { et al. } 2008 \\
\text { [55] }\end{array}$ & 11 & Soy milk & $\begin{array}{l}\text { Volume: Baseline } 58 \mu \mathrm{L} \\
1 \text { month } 105 \mu \mathrm{L} ; \mathrm{P}=0.47 \\
\text { Isoflavonoids: } \\
\text { baseline } 66 \mathrm{nmol} / \mathrm{L} \\
\text { } 1 \text { month } 180 \mathrm{nmol} / \mathrm{L} ; \mathrm{P}=0.12\end{array}$ & Urinary isoflavonoids: significant increase; $p=0.04$ \\
\hline $\begin{array}{l}\text { Maskarinec } \\
\text { et al. } 2011 \\
{[48,59]}\end{array}$ & 82 & Soy foods & $\begin{array}{l}\text { Volume: } \\
\text { low-soy } 28 \pm 34 \mu \mathrm{L} \\
\text { ligh-soy } 33 \pm 35 \mu \mathrm{L} ; \mathrm{p}=0.52 \\
\mathrm{E}_{2} \text { : } \\
\text { low-soy } 313 \pm 131 \mathrm{pg} / \mathrm{mL} \\
\text { high-soy } 113 \pm 123 \mathrm{pg} / \mathrm{mL} ; \mathrm{p}=0.07 \\
\mathrm{E}_{1} \text { S: } \\
\text { l low-soy } 68 \pm 115 \mathrm{ng} / \mathrm{mL} \\
\text { high-soy } 46 \pm 69 \mathrm{ng} / \mathrm{mL} ; \mathrm{p}=0.07\end{array}$ & $\begin{array}{l}\text { Serum } E_{2}, E_{1}, E_{1} S \text { : no change } \\
\text { Urinary isoflavonoids: significant increase } \\
\text { Urinary estrogen metabolites: no change } \\
\text { 2/16 } \alpha \text {-OHE1 ratio: increase; } p=0.05\end{array}$ \\
\hline $\begin{array}{l}\text { Khan et al. } \\
2012 \text { [57] }\end{array}$ & 98 & $\begin{array}{l}\text { Soy isoflavone } \\
\text { supplement }\end{array}$ & $\begin{array}{l}\text { Genistein: } \\
\text { treated } 8 \mu \mathrm{L} \\
\text { placebo } 11.5 \mu \mathrm{L} ; \mathrm{p}=0.63 \\
\mathrm{E}_{2} \text { : } \\
\text { treated } 354 \mathrm{pg} / \mathrm{mL} \\
\text { placebo } 91 \mathrm{pg} / \mathrm{mL} ; \mathrm{p}=0.64 \\
\text { IGF-I: } \\
\text { treated } 11.4 \mathrm{ng} / \mathrm{mL} \\
\text { placebo } 23.4 \mathrm{ng} / \mathrm{mL} ; \mathrm{p}=0.83\end{array}$ & $\begin{array}{l}\text { Plasma genistein: increase; } p<0.0001 \\
\text { Plasma } E_{2} \text { : no difference; } p=0.77 \\
\text { SHBG: } \text { no difference; } p=0.43 \\
\text { FSH: } \text { no difference; } p=0.45 \\
\text { Ki-67 in epithelial cells: } \text { no difference; } p=0.24 \\
\text { Atypical cytology: no difference; } p=0.83 \\
\text { Gene expression: no difference }\end{array}$ \\
\hline
\end{tabular}

en its close contact with breast cells, NAF is thought to provide a more relevant marker of hormonal influence on breast tissue than serum; correlations between hormone levels in NAF and serum are weak [49]. Women who produce NAF appear to be at a higher risk to develop breast cancer [50,51], but the higher risk is primarily present in women with cellular NAF and atypical cells [52].

The first study to investigate the effects of soy on NAF ( $\square$ Table 1) was a single-arm intervention among 24 pre- and postmenopausal Caucasian women with $38 \mathrm{~g}$ soy protein isolate [53]. Each woman served as her own control and donated NAF monthly for 6 months of soy supplementation and 3 months preceding and following the active intervention. A minimal increase or no response was found in postmenopausal women. In the 14 premenopausal women, the volume of NAF increased 2- to 6-fold after soy intake as compared to baseline. Whereas hyperplastic cells in NAF were found only in one woman at baseline, they were present in 7 women during soy protein intake. Although the implications of finding hyperplastic cells are not well understood, this study raised concern that NAF secretors may be sensitive to soy and react with increased secretion and cell proliferation [54]. However, this suggestion was not confirmed in later studies (० Table 1).
In a small study with 11 women who consumed 2 daily servings of soy milk for 30 days, isoflavonoid levels in NAF increased substantially [55]; median levels were $66 \mathrm{nM}$ at baseline and $180 \mathrm{nM}$ at the end (median increase of $58 \mathrm{nM} ; \mathrm{p}=0.12$ ). As a result of a soy challenge in one woman, isoflavonoid levels changed to a similar degree in NAF as in plasma and in urine with correlations $>0.8$ but were 10 -fold lower in NAF (12-94 nmol/L) than in plasma (46-1141 nmol/L) and comparable to concentrations in breast milk [56].

Three additional phytoestrogen trials ( Table 1) with NAF measures as endpoints were conducted, one with soy foods [48], one with an isoflavone supplement [57], and one with black cohosh, a phytoestrogen-containing plant [58]. A randomized cross-over study in Hawaii administered a high-soy diet and a low-soy diet for 6 months each [48]. The nutritional intervention of 2 daily servings of soy foods did not significantly increase breast tissue activity as assessed by NAF volume [48] or modify estrogen levels in NAF and serum although a trend of lower $E_{2}$ and $E_{1} S$ in NAF after the high-soy diet was observed [59]. The analysis of baseline measurements showed a nonsignificant inverse association of soy intake with NAF volume $(\mathrm{p}=0.08)$ but not with estrogen levels in NAF [60].

In a clinical trial of soy isoflavone supplements described in more detail below [57], NAF hormone and protein levels were mea- 
sured, but no treatment effects on NAF parameters were observed. No effect of a black cohosh preparation on pS2, a marker of estrogenic activity, or cellular morphology in NAF was seen during a 12-week trial with 45 women [58].

With the exception of the studies in Hawaii $[48,55,59]$, none of the NAF studies included women of Asian ancestry, but even in the Hawaii studies the numbers were too small for separate analysis. As reported previously, NAF production rates tend to be low in women of Japanese and Chinese ancestry [48,61], an observation that was confirmed in the soy intervention described above; only $26 \%$ of Asian candidates screened for participation produced $\mathrm{a} \geq 10 \mu \mathrm{L}$ amount of NAF, whereas $47 \%$ of Caucasian women were able to do so [48].

\section{Breast tissue analyses}

Studies in primates provide evidence that dietary exposure to isoflavones alone is not a significant estrogen agonist for breast tissue [62]. Soy treatment did not induce proliferation in mammary tissue but mammary gland proliferation induced by $E_{2}$ as assessed by increased epithelial staining of the proliferation marker Ki-67 was antagonized by soy in surgically postmenopausal female macaques. In humans, four approaches have been applied to assess the effects of isoflavones directly in breast tissue: specimens from breast reduction surgery, fine needle biopsies, samples obtained during breast cancer surgery, and formalinembedded pathologic specimens.

Two reports examined isoflavonoids in breast tissue from reduction surgery after 5 days of soy supplementation $[63,64]$. In trials with 28 and 31 Caucasian women, isoflavonoid concentrations were considerably lower in hydrolyzed breast tissue than in the corresponding serum samples $[63,64]$, but the high proportion of fat cells does not allow firm conclusions about epithelial breast tissue.

In a well-designed clinical trial [57], 126 high-risk women underwent a random fine-needle aspiration; those with 4000 or more epithelial cells were randomized to a double-blind 6-month intervention of soy isoflavones or placebo, followed by another fine-needle aspiration. The median Ki-67 labeling index was 1.18 at entry and 1.12 post-intervention in the 49 treated women, while it was 0.97 and 0.92 in 49 placebo subjects $(p=0.32)$. Menopausal stratification yielded similar results between groups, but within premenopausal soy-treated women, the Ki67 labeling index increased more than in postmenopausal women. No treatment effects on cytologic atypia or NAF parameters were observed. Although increases in the expression of 14 of 28 genes related to proliferation, apoptosis, and estrogenic effect were observed within the soy group, the difference between groups was not significant.

Several studies were performed among women scheduled to receive a breast biopsy or to undergo surgery [65,66]. Among 48 women who consumed a 60 -g soy supplement for 14 days before a breast biopsy [66], progesterone expression and the proliferation rate of breast lobular epithelium increased. The same investigators reported higher pS2 levels in the breast fluid of 84 premenopausal women in response to soy indicating an estrogenic stimulus [65]. A pilot clinical trial examined the interaction between 2 weeks of an isoflavone supplement and breast cancer growth among 17 patients [67]. The surgical breast cancer tissues and blood obtained prior to and after isoflavone supplement treatment were compared to 26 historical controls with similar characteristics. The apoptosis/mitosis ratios in isoflavone-treated cancer specimens were not significantly different from those of control untreated cancer specimens.

In a study using paraffin-embedded blocks from 268 breast cancer patients [68], hormonal and proliferation markers were examined in benign and malignant breast tissue using tissue microarrays (TMAs). The TMAs were stained for $\mathrm{ER} \alpha$, ER $\beta$, progesterone receptor (PR), human epidermal growth factor receptor 2 (HER2/ neu), proliferating cell nuclear antigen (PCNA), and Ki-67. With the exception of lower HER2/neu expression, no significant associations between soy intake and pathologic markers were observed in malignant tissue. In benign tissue, early life soy intake showed higher ER and PR expression, but no difference in proliferation markers. After stratification by ethnicity, slightly divergent results were observed for the association of adult soy intake with PR and Ki-67. Whereas in Caucasians, higher soy intake suggested higher marker expression, the relation was in the opposite direction among Japanese women, but none of the results was statistically significant [68].

\section{Possible Mechanisms for Ethnic Differences \\ $\nabla$}

Two obvious reasons why Asian populations may experience more beneficial health effects from soy foods than Western populations [15] are the high amounts and the types of soy foods commonly consumed in Asian countries. Typical intakes based on dietary surveys indicate that Asian populations consume as much as $25 \mathrm{~g}$ of soy protein or $100 \mathrm{mg}$ of isoflavones per day, whereas a Western diet provides less than $1 \mathrm{~g}$ of soy protein or $1 \mathrm{mg}$ of isoflavones per day [15]. Secondly, isoflavones from fermented soy foods, such as miso and natto, may be more bioavailable than non-fermented products, e.g., tofu and soy milk, because the glucosides in the latter require hydrolyzation to aglycones by intestinal bacteria before uptake is possible, whereas aglycones in fermented soy foods do not $[69,70]$.

Support for the idea that chronic ingestion and ethnic origin may influence isoflavone pharmacokinetics and bioavailability comes from a report that compared healthy young Asian and Caucasian men [71]. After consuming soya-based cheese with $46 \mathrm{mg}$ isoflavones as part of a Western diet, the 12 Asians exhibited significantly higher maximum plasma concentrations and areas under the plasma concentration-time curve for genistein and daidzein than the 12 Caucasians, in whom both values only increased after chronic intake.

\section{Genetic variation in metabolic enzymes}

Not all individuals may benefit from soy food exposure to the same degree due to variations in genes that metabolize isoflavones [72]. The dramatic variability in interindividual response to any type of dietary intervention may be the result of gene-diet interactions, i.e., the modulation of the effect of a dietary component by a genetic variant [72]. For example, genetic polymorphisms in the cytochrome P450 (CYP) or catechol-Omethyltransferase (COMT) enzymes may alter activity or modulate the expression of genes involved in metabolic pathways of estrogens and estrogen-like compounds $[73,74]$. There is limited research in this area, but a few studies from Asian countries reported interesting findings. A Chinese breast cancer study observed differential effects of CYP1A1, CYP1B1, and COMT polymorphisms after stratification by soy intake [75]. In addition, several Japanese studies describe a genetic influence on the effect of isoflavones. Polymorphisms in gene coding for $17 \beta$-hydroxy- 
steroid dehydrogenase type I and for sex hormone-binding globulin [76] as well as for ER $\beta$ [77] modified the association between isoflavone intake and breast cancer risk. Similarly, specific polymorphic variations appeared to influence the association of soy intake with prostate cancer [78] and testosterone levels [79].

\section{Timing of exposure}

As has been shown in animals, the overall effect of soy foods on carcinogenesis may depend on the time of life when isoflavones were administered due to the possibility that isoflavones exert estrogenic or antiestrogenic effects depending on the hormonal environment during different stages of life [17]. Since experimental studies indicate that estrogen exposure in young animals induces protection against cancer development [80,81], the weak estrogenic effects of isoflavones in soy beans, if consumed early in life, may achieve or accelerate differentiation of breast tissue structures similar to an early pregnancy and, thereby, decrease tissue susceptibility to carcinogens and prevent tumor development later in life. A number of case-control studies assessed soy intake during childhood or adolescence and found a stronger protection for early life than adult soy intake [82-85]. Noteworthy is the observation from a California study that Asia-born women experience more protection from soy consumption than US-born women of Japanese and Chinese ancestry [86]. This may explain why breast cancer incidence rates in Asian migrants reached levels of the US population over consecutive generations as early life exposure to soy foods declined [87].

\section{Intestinal metabolism by microbiota}

Given the need for bacterial action before uptake of glycosides, the bioavailability of isoflavones varies substantially across individuals [71]. In addition, the possible importance of equol production, i.e., the capacity of the intestinal bacteria to metabolize the isoflavone dadzein into the metabolite equol may confer a greater protection against disease than the other isoflavonoids $[88,89]$. This trait has been proposed as an explanation for the more commonly found positive associations between soy foods and health in Asians because the prevalence of equol production appears to be higher in Asian (50-55\%) than Western (20-35\%) populations [90-92]. Experimental support for this idea comes from a study showing that isoflavones differentially induce gene expression changes in lymphocytes from women who form equol as compared to nonproducers [93]. However, an analysis of equol levels in repeated samples challenges the widely held belief that equol status remains stable within individuals over time; $16 \%$ of premenopausal participants with diverse ethnic backgrounds were inconsistent equol producers in a 1-year period [94] and 14-35\% of predominantly Caucasian postmenopausal women changed equol status over 2.5 years [95].

As the increasing importance of gut microbiota in human health is emerging [96], it has become apparent that patterns of intestinal bacteria acquired during gut colonization in early life are related to dietary exposure and geographic location [97]. Thus, infants exposed to isoflavones early in life may become more competent to hydrolyze glycosides allowing uptake of isoflavones and to produce equol later in life as suggested by a comparison between Korean American and Caucasian girls [90]. Given the high levels of isoflavones in breast milk when mothers consume soy foods $[98,99]$, the acquisition of bacteria that are capable of metabolizing isoflavones may begin during infancy [100], but later events continue to modify bacteria composition. At this time, little is known about how early life isoflavone exposure deter- mines equol status later in life [101] and which specific bacteria are able to metabolize isoflavones or produce equol although a few bacteria have been identified $[100,102]$.

\section{Conclusions}

$\nabla$

One of the more consistent findings in soy research is the fact that epidemiologic studies report a stronger protective effect of soy foods against breast cancer among women who grew up in Asian countries and in those who consumed soy foods throughout childhood and adolescence [13]. As to other cancer sites, a meta-analysis of prostate cancer studies also supports the idea of ethnic differences. A lower risk associated with soy consumption was observed only among Asian (OR $=0.52$; 95\% CI: $0.33-$ 0.81 ) but not Western populations ( $\mathrm{OR}=0.99$; $95 \% \mathrm{CI}$ : $0.85-$ 1.16) [103]. On the other hand, the Multiethnic Cohort described similar associations between urinary isoflavone excretion and prostate cancer across ethnic groups [104]. Smaller meta-analyses for less studied sites, such as endometrial, ovarian, and colorectal cancer, described only small differences in associations by ethnicity $[105,106]$.

The current body of literature is insufficient to answer the question whether women of diverse ethnic groups experience distinct effects from soy isoflavones in breast tissue; only a limited number of comparative studies address differences in biomarkers between Asian and Western populations, and very few interventions included women of Asian ancestry. Nevertheless, ethnic differences in the prevalence of biomarkers discussed in this review are evident. Asian women have lower levels of sex steroids and higher mammographic densities. Also, they are less likely to produce NAF and more likely to convert isoflavones to equol. However, information that addresses effect modification of the association between soy and breast cancer risk by ethnicity is more limited. Based on the current evidence, soy consumption might have a stronger association with mammographic densities [39,40], and possibly estrogen levels [20] in Asian than Western women. The low rate of NAF production and a lack of breast tissue studies in Asian women challenge our ability to explore soy food intake in relation to breast cell and tissue measures. Comparisons of biomarkers in Asian and Caucasian women have contributed considerably to our knowledge about ethnic differences in breast cancer risk and elucidated biologic mechanisms of action for isoflavones in relation to breast carcinogenesis. Based on the current evidence, it appears likely that the timing of soy exposure is the most important determinant of beneficial health effects. Since reports about cancer-protective effects of soy come primarily from Asian populations who consumed soy foods since childhood, diet in early life may be more important than adult nutrition. This may be due to gut microbiota, which colonize the intestine during infancy and facilitate the hydrolysis of glycosides for improved bioavailability and the formation of equol from dadzein, a pathway that may result in beneficial health effects. As knowledge about the role of early life nutrition and the development of gut microbiota and their functions increases, the potential for diverse metabolic pathways of isoflavones in Asian individuals may be clarified.

\section{Conflict of Interest \\ $\nabla$}

The author declares that there is no conflict of interest. 


\section{References}

1 Smil V. Magic beans. Nature 2000; 407: 567

2 Kolonel LN, Wilkens LR. Migrant studies. In: Schottenfeld D, Fraumeni JF, editors. Cancer epidemiology and prevention. New York: Oxford University Press; 2006: 189-201

3 Ferlay J, Shin HR, Bray F, Forman D, Mathers C, Parkin DM. GLOBOCAN 2008 v1.2: Cancer incidence and mortality worldwide: IARC CancerBase No. 10. Available at http://globocan.iarc.fr. Accessed April 12, 2012

4 Shimizu H, Ross RK, Bernstein L, Yatani R, Henderson BE, Mack TM. Cancers of the prostate and breast among Japanese and white immigrants in Los Angeles County. Br J Cancer 1991; 63: 963-966

5 Colditz GA, Baer HJ, Tamimi RM. Breast cancer. In: Schottenfeld D, Fraumeni JF, editors. Cancer epidemiology and prevention. New York: Oxford University Press; 2006: 189-201

6 Adlercreutz H. Phyto-oestrogens and cancer. Lancet Oncol 2002; 3: 364-373

7 Oseni T, Patel R, Pyle J, Jordan VC. Selective estrogen receptor modulators and phytoestrogens. Planta Med 2008; 74: 1656-1665

8 Virk-Baker MK, Nagy TR, Barnes S. Role of phytoestrogens in cancer therapy. Planta Med 2010; 76: 1132-1142

9 Barnes S, Kim H, Darley-Usmar V, Patel R, Xu J, Boersma B, Luo M. Beyond ERalpha and ERbeta: estrogen receptor binding is only part of the isoflavone story. J Nutr 2000; 130: 656S-657S

10 Yan L, Spitznagel E. A meta-analysis of soyfoods and risk of breast cancer in women. Int J Cancer Prev 2004; 1: 281-293

11 Trock BJ, Hilakivi-Clarke L, Clarke R. Meta-analysis of soy intake and breast cancer risk. J Natl Cancer Inst 2006; 98: 459-471

12 Qin LQ Xu JY, Wang PY, Hoshi K. Soyfood intake in the prevention of breast cancer risk in women: a meta-analysis of observational epidemiological studies. J Nutr Sci Vitaminol (Tokyo) 2006; 52: 428-436

$13 \mathrm{Wu} A H, Y u$ MC, Tseng CC, Pike MC. Epidemiology of soy exposures and breast cancer risk. Br J Cancer 2008; 98: 9-14

14 Dong JY, Qin LQ. Soy isoflavones consumption and risk of breast cancer incidence or recurrence: a meta-analysis of prospective studies. Breast Cancer Res Treat 2011; 125: 315-323

15 Messina M, Nagata $C, W u A H$. Estimated Asian adult soy protein and isoflavone intakes. Nutr Cancer 2006; 55: 1-12

16 Goodman MT, Shvetsov YB, Wilkens LR, Franke AA, Le ML, Kakazu KK, Nomura AM, Henderson BE, Kolonel LN. Urinary phytoestrogen excretion and postmenopausal breast cancer risk: the multiethnic cohort study. Cancer Prev Res (Phila Pa) 2009; 2: 887-894

17 Collins-Burow BM, Burow ME, Duong BN, McLachlan JA. Estrogenic and antiestrogenic activities of flavonoid phytochemicals through estrogen receptor binding-dependent and -independent mechanisms. Nutr Cancer 2000; 38: 229-244

18 Setchell $K D$. Soy isoflavones-benefits and risks from nature's selective estrogen receptor modulators (SERMs). J Am Coll Nutr 2001; 20: 354S$362 S$

19 Kuiper GG, Gustafsson JA. The novel estrogen receptor-beta subtype: potential role in the cell- and promoter-specific actions of estrogens and anti-estrogens. FEBS Lett 1997; 410: 87-90

20 Hooper L, Ryder JJ, Kurzer MS, Lampe JW, Messina MJ, Phipps WR, Cassidy $A$. Effects of soy protein and isoflavones on circulating hormone concentrations in pre- and post-menopausal women: a systematic review and meta-analysis. Hum Reprod Update 2009; 15: 423-440

$21 \mathrm{Xu}$ X, Duncan AM, Wangen KE, Kurzer MS. Soy consumption alters endogenous estrogen metabolism in postmenopausal women. Cancer Epidemiol Biomarkers Prev 2000; 9: 781-786

22 Lu LJ, Cree M, Josyula S, Nagamani M, Grady JJ, Anderson KE. Increased urinary excretion of 2-hydroxyestrone but not 16alpha- hydroxyestrone in premenopausal women during a soya diet containing isoflavones. Cancer Res 2000; 60: 1299-1305

23 Morimoto Y, Conroy SM, Pagano IS, Isaki M, Franke AA, Nordt FJ, Maskarinec $G$. Urinary estrogen metabolites during a randomized soy trial. Nutr Cancer 2012; 64: 307-314

24 Wu AH, Stanczyk FZ, Hendrich S, Murphy PA, Zhang C, Wan P, Pike MC. Effects of soy foods on ovarian function in premenopausal women. $\mathrm{Br}$ J Cancer 2000; 82: 1879-1886

25 Nagata C, Takatsuka N, Inaba S, Kawakami N, Shimizu H. Effect of soymilk consumption on serum estrogen concentrations in premenopausal Japanese women. J Natl Cancer Inst 1998; 90: 1830-1835

26 Tsuji M, Tamai Y, Wada K, Nakamura K, Hayashi M, Takeda N, Yasuda K, Nagata C. Associations of intakes of fat, dietary fiber, soy isoflavones, and alcohol with levels of sex hormones and prolactin in premenopausal Japanese women. Cancer Causes Control 2012; 23: 683-689
27 Uesugi S, Watanabe S, Ishiwata N, Uehara M, Ouchi K. Effects of isoflavone supplements on bone metabolic markers and climacteric symptoms in Japanese women. Biofactors 2004; 22: 221-228

28 Huang HY, Yang HP, Yang HT, Yang TC, Shieh MJ, Huang SY. One-year soy isoflavone supplementation prevents early postmenopausal bone loss but without a dose-dependent effect. J Nutr Biochem 2006; 17: 509517

29 Wu J, Oka J, Higuchi M, Tabata I, Toda T, Fujioka M, Fuku N, Teramoto T, Okuhira T, Ueno T, Uchiyama S, Urata K, Yamada K, Ishimi Y. Cooperative effects of isoflavones and exercise on bone and lipid metabolism in postmenopausal Japanese women: a randomized placebo-controlled trial. Metabolism 2006; 55: 423-433

30 Fuhrman BJ, Pfeiffer R, Xu X, Wu AH, Korde L, Gail MH, Keefer LK, Veenstra TD, Hoover RN, Ziegler RG. Soy intake is associated with increased 2-hydroxylation and decreased 16alpha-hydroxylation of estrogens in Asian-American women. Cancer Epidemiol Biomarkers Prev 2009; 18: 2751-2760

31 Martini MC, Dancisak BB, Haggans CJ, Thomas W, Slavin JL. Effects of soy intake on sex hormone metabolism in premenopausal women. Nutr Cancer 1999; 34: 133-139

32 Maskarinec G, Franke AA, Williams AE, Stanczyk FC. The effects of an isoflavone intervention on the urinary excretion of hormone metabolites in premenopausal women. IARC Sci Publ 2002; 156: 375-377

33 Xu X, Duncan AM, Merz BE, Kurzer MS. Effects of soy isoflavones on estrogen and phytoestrogen metabolism in premenopausal women. Cancer Epidemiol Biomarkers Prev 1998; 7: 1101-1108

34 Teas J, Hurley TG, Hebert JR, Franke AA, Sepkovic DW, Kurzer MS. Dietary seaweed modifies estrogen and phytoestrogen metabolism in healthy postmenopausal women. J Nutr 2009; 139: 939-944

35 Nettleton JA, Greany KA, Thomas W, Wangen KE, Adlercreutz H, Kurzer MS. The effect of soy consumption on the urinary 2: 16-hydroxyestrone ratio in postmenopausal women depends on equol production status but is not influenced by probiotic consumption. J Nutr 2005; 135: 603-608

36 McCormack VA, dos Santos Silva I. Breast density and parenchymal patterns as markers of breast cancer risk: a meta-analysis. Cancer Epidemiol Biomarkers Prev 2006; 15: 1159-1169

37 Maskarinec G, Pagano I, Chen Z, Nagata C, Gram IT. Ethnic and geographic differences in mammographic density and their association with breast cancer incidence. Breast Cancer Res Treat 2007; 104: 4756

38 Maskarinec G, Meng L. An investigation of soy intake and mammographic characteristics in Hawaii. Breast Cancer Res 2001; 3: 134-141

39 Jakes RW, Duffy SW, Ng FC, Gao F, Ng EH, Seow A, Lee HP, Yu MC. Mammographic parenchymal patterns and self-reported soy intake in Singapore Chinese women. Cancer Epidemiol Biomarkers Prev 2002; 11: 608-613

40 Ursin G, Sun CL, Koh WP, Khoo KS, Gao F, Wu AH, Yu MC. Associations between soy, diet, reproductive factors, and mammographic density in Singapore Chinese women. Nutr Cancer 2006; 56: 128-135

41 Nagata C, Matsubara T, Fujita H, Nagao Y, Shibuya C, Kashiki Y, Shimizu $H$. Associations of mammographic density with dietary factors in Japanese women. Cancer Epidemiol Biomarkers Prev 2005; 14: 2877-2880

42 Wu AH, Ursin G, Koh WP, Wang R, Yuan JM, Khoo KS, Yu MC. Green tea, soy, and mammographic density in Singapore Chinese women. Cancer Epidemiol Biomarkers Prev 2008; 17: 3358-3365

43 Maskarinec G, Verheus M, Tice J. Epidemiologic studies of isoflavones \& mammographic density. Nutrients 2010; 2: 35-48

44 Hooper L, Madhavan G, Tice JA, Leinster SJ, Cassidy A. Effects of isoflavones on breast density in pre- and post-menopausal women: a systematic review and meta-analysis of randomized controlled trials. Hum Reprod Update 2010; 16: 745-760

45 Maskarinec G, Takata Y, Franke AA, Williams AE, Murphy SP. A 2-year soy intervention in premenopausal women does not change mammographic densities. J Nutr 2004; 134: 3089-3094

46 Maskarinec G, Williams AE, Carlin L. Mammographic densities in a oneyear isoflavone intervention. Eur J Cancer Prev 2003; 12: 165-169

47 Franke AA, Halm BM, Custer LJ, Tatsumura Y, Hebshi S. Isoflavones in breastfed infants after mothers consume soy. Am J Clin Nutr 2006; 84: 406-413

48 Maskarinec G, Morimoto Y, Conroy SM, Pagano IS, Franke AA. The volume of nipple aspirate fluid is not affected by 6 months of treatment with soy foods in premenopausal women. J Nutr 2011; 141: 626-630 
49 Chatterton Jr. RT, Geiger AS, Gann PH, Khan SA. Formation of estrone and estradiol from estrone sulfate by normal breast parenchymal tissue. J Steroid Biochem Mol Biol 2003; 86: 159-166

50 Wrensch MR, Petrakis NL, Miike R, King EB, Chew K, Neuhaus J, Lee MM, Rhys $M$. Breast cancer risk in women with abnormal cytology in nipple aspirates of breast fluid. J Natl Cancer Inst 2001; 93: 1791-1798

51 Tice JA, Miike R, Adduci K, Petrakis NL, King E, Wrensch MR. Nipple aspirate fluid cytology and the Gail model for breast cancer risk assessment in a screening population. Cancer Epidemiol Biomarkers Prev 2005; 14: 324-328

52 Buehring G, Letscher A, McGirr K, Khandhar S, Che L, Nguyen C, Hackett $A$. Is presence of nipple aspirate fluid and cells related to subsequent development of breast cancer? A 25-year prospective study. Proc Am Assoc Cancer Res 2005; 46: 4046

53 Petrakis NL, Barnes S, King EB, Lowenstein J, Wiencke J, Lee MM, Miike R, Kirk M, Coward L. Stimulatory influence of soy protein isolate on breast secretion in pre-and postmenopausal women. Cancer Epidemiol Biomarkers Prev 1996; 5: 785-794

54 Messina MJ, Loprinzi CL. Soy for breast cancer survivors: a critical review of the literature. J Nutr 2001; 131: 3095S-3108S

55 Maskarinec G, Hebshi S, Custer L, Franke AA. The relation of soy intake and isoflavone levels in nipple aspirate fluid. Eur J Cancer Prev 2008; 17: $67-70$

56 Franke AA, Custer LJ, Tanaka Y. Isoflavones in human breast milk and other biological fluids. Am J Clin Nutr 1998; 68: 1466S-1473S

57 Khan SA, Chatterton RT, Michel N, Bryk M, Lee O, Ivancic D, Heinz R, Zalles CM, Helenowski IB, Jovanovic BD, Franke AA, Bosland MC, Wang J, Hansen NM, Bethke KP, Dew A, Coomes M, Bergan RC. Soy isoflavone supplementation for breast cancer risk reduction: a randomized phase II trial. Cancer Prev Res (Phila) 2012; 5: 309-319

58 Ruhlen RL, Haubner J, Tracy JK, Zhu W, Ehya H, Lamberson WR, Rottinghaus GE, Sauter ER. Black cohosh does not exert an estrogenic effect on the breast. Nutr Cancer 2007; 59: 269-277

59 Maskarinec G, Ollberding NJ, Conroy SM, Morimoto Y, Pagano IS, Franke $A A$, Gentzschein E, Stanczyk FZ. Estrogen levels in nipple aspirate fluid and serum during a randomized soy trial. Cancer Epidemiol Biomarkers Prev 2011; 20: 1815-1821

60 Morimoto Y, Conroy SM, Pagano IS, Franke AA, Stanczyk FZ, Maskarinec $G$. Influence of diet on nipple aspirate fluid production and estrogen levels. Food Funct 2011; 2: 665-670

61 Petrakis NL, Lee MM, Wrensch MR, Ernster VL, Miike R, Koo LC, Ho JC. Birthplace and yield of nipple aspirate fluid in Chinese women. Cancer Epidemiol Biomarkers Prev 1998; 7: 835-839

62 Wood CE, Kaplan JR, Stute P, Cline JM. Effects of soy on the mammary glands of premenopausal female monkeys. Fertil Steril 2006; 85 (Suppl. 1): 1179-1186

63 Maubach J, Depypere HT, Goeman J, Van der EJ, Heyerick A, Bracke ME, Blondeel P, De Keukeleire D. Distribution of soy-derived phytoestrogens in human breast tissue and biological fluids. Obstet Gynecol 2004; 103 : 892-898

64 Bolca S, Urpi-Sarda M, Blondeel P, Roche N, Vanhaecke L, Possemiers S, AlMaharik N, Botting N, De KD, Bracke M, Heyerick A, Manach C, Depypere $H$. Disposition of soy isoflavones in normal human breast tissue. Am J Clin Nutr 2010; 91: 976-984

65 Hargreaves DF, Potten CS, Harding C, Shaw LE, Morton MS, Roberts SA, Howell A, Bundred NJ. Two-week dietary soy supplementation has an estrogenic effect on normal premenopausal breast. J Clin Endocrinol Metab 1999; 84: 4017-4024

66 McMichael-Phillips DF, Harding C, Morton M, Roberts SA, Howell A, Potten CS, Bundred NJ. Effects of soy-protein supplementation on epithelial proliferation in the histologically normal human breast. Am J Clin Nutr 1998; 68: 1431S-1435S

67 Sartippour MR, Rao JY, Apple S, Wu D, Henning S, Wang H, Elashoff R, Rubio $R$, Heber D, Brooks MN. A pilot clinical study of short-term isoflavone supplements in breast cancer patients. Nutr Cancer 2004; 49: 59-65

68 Maskarinec G, Erber E, Verheus M, Hernandez BY, Killeen J, Cashin S, Cline JM. Soy consumption and histopathologic markers in breast tissue using tissue microarrays. Nutr Cancer 2009; 61: 708-716

69 Kano M, Takayanagi T, Harada K, Sawada S, Ishikawa F. Bioavailability of isoflavones after ingestion of soy beverages in healthy adults. J Nutr 2006; 136: 2291-2296

70 Zubik L, Meydani M. Bioavailability of soybean isoflavones from aglycone and glucoside forms in American women. Am J Clin Nutr 2003; 77: 1459-1465
71 Vergne S, Sauvant P, Lamothe V, Chantre P, Asselineau J, Perez P, Durand $M$, Moore N, Bennetau-Pelissero C. Influence of ethnic origin (Asian v. Caucasian) and background diet on the bioavailability of dietary isoflavones. Br J Nutr 2009; 102: 1642-1653

72 Ordovas JM. Genotype-phenotype associations: modulation by diet and obesity. Obesity (Silver Spring) 2008; 16 (Suppl. 3): S40-S46

73 Zhu BT. Catechol-O-Methyltransferase (COMT)-mediated methylation metabolism of endogenous bioactive catechols and modulation by endobiotics and xenobiotics: importance in pathophysiology and pathogenesis. Curr Drug Metab 2002; 3: 321-349

74 Thompson PA, Ambrosone C. Molecular epidemiology of genetic polymorphisms in estrogen metabolizing enzymes in human breast cancer. J Natl Cancer Inst Monogr 2000; 2000: 125-134

75 Wang $Q$ Li H, Tao P, Wang YP, Yuan P, Yang CX, Li JY, Yang F, Lee H, Huang $Y$. Soy isoflavones, CYP1A1, CYP1B1, and COMT polymorphisms, and breast cancer: a case-control study in southwestern China. DNA Cell Biol 2011; 30: 585-595

76 Iwasaki M, Hamada GS, Nishimoto IN, Netto MM, Motola Jr. J, Laginha FM, Kasuga Y, Yokoyama S, Onuma H, Nishimura H, Kusama R, Kobayashi M, Ishihara J, Yamamoto S, Hanaoka T, Tsugane S. Dietary isoflavone intake, polymorphisms in the CYP17, CYP19, 17beta-HSD1, and SHBG genes, and risk of breast cancer in case-control studies in Japanese, Japanese Brazilians, and non-Japanese Brazilians. Nutr Cancer 2010; 62: 466-475

77 Iwasaki M, Hamada GS, Nishimoto IN, Netto MM, Motola Jr. J, Laginha FM, Kasuga Y, Yokoyama S, Onuma H, Nishimura H, Kusama R, Kobayashi $M$, Ishihara J, Yamamoto $S$, Hanaoka $T$, Tsugane S. Isoflavone, polymorphisms in estrogen receptor genes and breast cancer risk in case-control studies in Japanese, Japanese Brazilians and non-Japanese Brazilians. Cancer Sci 2009; 100: 927-933

78 Hedelin M, Balter KA, Chang ET, Bellocco R, Klint A, Johansson JE, Wiklund F, Thellenberg-Karlsson C, Adami HO, Gronberg H. Dietary intake of phytoestrogens, estrogen receptor-beta polymorphisms and the risk of prostate cancer. Prostate 2006; 66: 1512-1520

79 Low YL, Taylor JI, Grace PB, Dowsett M, Folkerd E, Doody D, Dunning AM, Scollen S, Mulligan AA, Welch AA, Luben RN, Khaw KT, Day NE, Wareham NJ, Bingham SA. Polymorphisms in the CYP19 gene may affect the positive correlations between serum and urine phytoestrogen metabolites and plasma androgen concentrations in men. J Nutr 2005; 135: 2680 2686

80 Lamartiniere CA. Timing of exposure and mammary cancer risk. J Mammary Gland Biol Neoplasia 2002; 7: 67-76

81 Hilakivi-Clarke L, Cho E, DeAssis S, Olivo S, Ealley E, Bouker KB, Welch JN, Khan $G$, Clarke R, Cabanes A. Maternal and prepubertal diet, mammary development and breast cancer risk. J Nutr 2001; 131: 154S-157S

82 Shu XO, Jin F, Dai Q Wen W, Potter JD, Kushi LH, Ruan Z, Gao YT, Zheng W. Soyfood intake during adolescence and subsequent risk of breast cancer among Chinese women. Cancer Epidemiol Biomarkers Prev 2001; 10: $483-488$

83 Wu AH, Wan P, Hankin J, Tseng CC, Yu MC, Pike MC. Adolescent and adult soy intake and risk of breast cancer in Asian-Americans. Carcinogenesis 2002; 23: 1491-1496

84 Korde LA, Wu AH, Fears T, Nomura AM, West DW, Kolonel LN, Pike MC, Hoover RN, Ziegler RG. Childhood soy intake and breast cancer risk in Asian American women. Cancer Epidemiol Biomarkers Prev 2009; 18: 1050-1059

85 Lee SA, Shu XO, Li H, Yang G, Cai H, Wen W, Ji BT, Gao J, Gao YT, Zheng W. Adolescent and adult soy food intake and breast cancer risk: results from the Shanghai Women's Health Study. Am J Clin Nutr 2009; 89: 1920-1926

86 Wu AH, Ziegler RG, Horn-Ross PL, Nomura AM, West DW, Kolonel LN, Rosenthal JF, Hoover RN, Pike MC. Tofu and risk of breast cancer in Asian-Americans. Cancer Epidemiol Biomarkers Prev 1996; 5: 901906

87 American Cancer Society, Cancer Research Center of Hawaii, Hawaii Department of Health. Hawaii cancer facts \& figures 2003-2004. Hawaii: American Cancer Society; 2004

88 Lampe JW. Emerging research on equol and cancer. J Nutr 2010; 140: 1369S-1372S

89 Setchell KD, Brown NM, Lydeking-Olsen E. The clinical importance of the metabolite equol-a clue to the effectiveness of soy and its isoflavones. J Nutr 2002; 132: 3577-3584

90 Song KB, Atkinson C, Frankenfeld CL, Jokela T, Wahala K, Thomas WK, Lampe JW. Prevalence of daidzein-metabolizing phenotypes differs be- 
tween Caucasian and Korean American women and girls. J Nutr 2006; 136: $1347-1351$

91 Setchell KD, Cole SJ. Method of defining equol-producer status and its frequency among vegetarians. J Nutr 2006; 136: 2188-2193

92 Lampe JW. Is equol the key to the efficacy of soy foods? Am J Clin Nutr 2009; 89: 1664S-1667S

93 Niculescu MD, Pop EA, Fischer LM, Zeisel SH. Dietary isoflavones differentially induce gene expression changes in lymphocytes from postmenopausal women who form equol as compared with those who do not. J Nutr Biochem 2007; 18: 380-390

94 Franke AA, Lai JF, Pagano I, Morimoto Y, Maskarinec G. Equol production changes over time in pre-menopausal women. Br J Nutr 2011; 107: 1201-1206

95 Franke AA, Lai JF, Halm BM, Pagano I, Kono N, Mack WJ, Hodis HN. Equol production changes over time in postmenopausal women. J Nutr Biochem 2012; 23: 573-579

96 Cho I, Blaser MJ. The human microbiome: at the interface of health and disease. Nat Rev Genet 2012; 13: 260-270

97 De Filippo C, Cavalieri D, Di PM, Ramazzotti M, Poullet JB, Massart S, Collini S, Pieraccini G, Lionetti P. Impact of diet in shaping gut microbiota revealed by a comparative study in children from Europe and rural Africa. Proc Natl Acad Sci USA 2010; 107: 14691-14696

98 Goodman AL, Kallstrom G, Faith JJ, Reyes A, Moore A, Dantas G, Gordon JI. Extensive personal human gut microbiota culture collections characterized and manipulated in gnotobiotic mice. Proc Natl Acad Sci USA 2011; 108: 6252-6257
99 Sela DA, Mills DA. Nursing our microbiota: molecular linkages between bifidobacteria and milk oligosaccharides. Trends Microbiol 2010; 18: 298-307

100 Tsuji H, Moriyama K, Nomoto K, Miyanaga N, Akaza H. Isolation and characterization of the equol-producing bacterium Slackia sp. strain NATTS. Arch Microbiol 2010; 192: 279-287

101 Hoey L, Rowland IR, Lloyd AS, Clarke DB, Wiseman H. Influence of soyabased infant formula consumption on isoflavone and gut microflora metabolite concentrations in urine and on faecal microflora composition and metabolic activity in infants and children. Br J Nutr 2004; 91 : 607-616

102 Matthies A, Blaut M, Braune A. Isolation of a human intestinal bacterium capable of daidzein and genistein conversion. Appl Environ Microbiol 2009; 75: 1740-1744

103 Yan L, Spitznagel EL. Soy consumption and prostate cancer risk in men: a revisit of a meta-analysis. Am J Clin Nutr 2009; 89: 1155-1163

104 Park SY, Wilkens LR, Franke AA, Le ML, Kakazu KK, Goodman MT, Murphy SP, Henderson BE, Kolonel LN. Urinary phytoestrogen excretion and prostate cancer risk: a nested case-control study in the Multiethnic Cohort. Br J Cancer 2009; 101: 185-191

105 Yan L, Spitznagel EL, Bosland MC. Soy consumption and colorectal cancer risk in humans: a meta-analysis. Cancer Epidemiol Biomarkers Prev 2010; 19: 148-158

106 Myung SK, Ju W, Choi HJ, Kim SC. Soy intake and risk of endocrine-related gynaecological cancer: a meta-analysis. BJOG 2009; 116: 1697 1705 